\title{
EVALUATIOM OF PHYSICAL AND MECHANICAL PROPERTIES OF PARTICLEBOARD PRODUCED FROM WOOD OF Cupressus torulosa IN MIXTURE WITH Pinus taeda
}

\author{
Setsuo Iwakiri ${ }^{1 *}$, Rosilani Trianoski ${ }^{1}$, Amanda Leite da Silva ${ }^{2}$, Angela Maria Stüpp ${ }^{2}$, Bruna Mulinari Cabral ${ }^{2}$, \\ Helena Cristina Vieira ${ }^{2}$ \\ 1*Federal University of Paraná, Department of Forest Engineering and Technology, Curitiba, Paraná, Brazil - e-mail: \\ setsuo.ufpr@gmail.com, rosillani@gmail.com \\ ${ }^{2}$ Federal University of Paraná, Graduate Program in Forest Engineering, Curitiba, Paraná, Brazil - e-mail: \\ eng.amandaleite@gmail.com; angela.stupp@hotmail.com; brunacabral@florestal.eng.br; lenacristin@hotmail.com \\ Received for publication: 02/10/2018 - Accepted for publication: 24/04/2020
}

\begin{abstract}
Resumo
Avaliação das propriedades físicas e mecânicas de painéis aglomerados produzidos com madeira de Cupressus torulosa em mistura com Pinus taeda. O objetivo deste trabalho foi avaliar as propriedades físicas e mecânicas de painéis aglomerados produzidos com 100\% de madeira de Cupressus torulosa D. Don., e diferentes proporções de mistura com Pinus taeda L. Os painéis experimentais foram produzidos com partículas de madeiras de Cupressus torulosa/Pinus taeda, nas proporções de 100/0\%, 80/20\%, 60/40\%, $40 / 60 \%, 20 / 80 \%$ e $0 / 100 \%$, totalizando seis tratamentos. Os painéis foram produzidos com densidade nominal de $0,75 \mathrm{~g} / \mathrm{cm}^{3}, 8 \%$ de resina ureia-formaldeído e $1 \%$ de emulsão de parafina. Foram realizados os ensaios de absorção de água e inchamento em espessura 2 e 24 horas, flexão estática (MOE e MOR), tração perpendicular (ligação interna) e arrancamento de parafuso. As avaliações comparativas dos resultados desta pesquisa com o Pinus taeda, outras espécies referenciadas na literatura, e requisitos normativos da EN 3122003 para painéis comerciais, indicaram grande potencial da madeira de Cupressus torulosa para produção de painéis aglomerados.

Palavras-chave: espécies de rápido crescimento; prensagem de painéis; resina ureia-formaldeído.
\end{abstract}

\begin{abstract}
The objective of this work was to evaluate the quality of particleboard produced with $100 \%$ of wood of Cupressus torulosa and in different mixing proportions with Pinus taeda. The experimental panels were produced with wood particles of Cupressus torulosa/Pinus taeda, in proportions of 100/0\%, 80/20\%, 60/40\%, $40 / 60 \%, 20 / 80 \%$ and $0 / 100 \%$, totaling six treatments. The panels were produced with nominal density of $0.75 \mathrm{~g} / \mathrm{cm}^{3}, 8 \%$ urea-formaldehyde resin and $1 \%$ paraffin emulsion. The quality of the panels was evaluated by water absorption and swelling thickness 2 and 24 hours, static bending (MOE and MOR), perpendicular tension (internal bonding) and screw withdrawal. The comparative evaluations of the results of this research, with the Pinus taeda, others species referenced in the literature, and normative requirements of EN 312-2003 for commercial panels, indicated great potential of the wood of Cupressus torulosa for the particleboard production.

Keywords: fast growing species; board pressing; urea-formaldehyde resin.
\end{abstract}

\section{INTRODUCTION}

The main source of raw material for the particleboard industries in Brazil comes from the planted forests of Pinus and Eucalyptus. Due to the high demand for wood from the pulp and paper industries, wood panels and sawmills, there is a need for studies on fast-growing alternative species for the formation of production forests for the supply of industrial raw materials.

In the last decades, studies have been conducted by several researchers on technological evaluations of wood of alternative species of fast growth aiming its use for the production of wood panels, such as Acrocarpus fraxinifolius Wight \& Arn., Toona ciliata M. Roem. and Melia azedarach L. (TRIANOSKI et al., 2011); Schizolobium amazonicum e Sida sp. (BIANCHE et al., 2012) Cryptomeria japonica (L) Don. (TRIANOSKI et al., 2013); Eucalyptus urophylla (NAUMANN et al., 2008); Sequoia sempervirens (D. Don) Endl. (IWAKIRI, et al., 2014); Cecropia pachystachya (MARTINS et al., 2014) ; Grevillea robusta A. Cunn (TRIANOSKI et al., 2016); Schizolobium amazonicum and Cecropia sp. (ZELLER et al., 2013). The results obtained by these researchers indicated the feasibility of using $100 \%$ of these species or in a mixture with Pinus woods for the production of particleboards.

The genus Cupressus is classified as a conifer, being known as Himalayan cypress trees, naturally occurring in southwest China, northeast India and Nepal. Its wood, extracted from some small-scale or

FLORESTA, Curitiba, PR, v. 50, n. 3, p. 1478 - 1485, jul/set 2020.

Iwakiri, S. et.al.

ISSN eletrônico 1982-4688

DOI: $10.5380 /$ rf.v50 i3. 61971 
experimental plantations, is used in Kenya; as a fuel source in Guatemala; for pulp production in Venezuela (OKINO et al., 2005). Experimental plantations in Brazil have shown good growth rates and, due to their low density wood, from 0.40 to $0.57 \mathrm{~g} / \mathrm{cm}^{3}$ (OKINO et al., 2010), it has great potential as a raw material for the paper and cellulose, laminated and plywood industries, in addition to particle and fiber boards (MALONEY, 1993). Specifically in the reconstituted panel industry, the application of species of this genus has shown technical feasibility in the production of OSB panels (OKINO et al., 2008) and side bonding panels (ALMEIDA, 2017).

The selection of wood species for the production of particleboard must be based on some parameters such as density, pH and extractives (MOSLEMI, 1974; MALONEY, 1993).

The density of wood is one of the basic requirements when choosing species for the production of particleboard, due to its influence on the compaction ratio, which is the relationship between the density of the panel and the density of the wood. According to Moslemi (1974) and Maloney (1993), the compaction ratio must be at least 1.3 to ensure an adequate contact area between the particles and sufficient densification for the formation of the panel.

Moslemi (1974) states that, for panels of the same nominal density, produced with low-density wood particles, their mechanical properties will be superior; however, their dimensional stability will be inferior in comparison to panels produced with high-density wood. According to the author, in panels with a higher compaction ratio, there is a greater amount of wood particles, resulting in a greater water absorption surface and less adhesive in the interfaces between the particles for bonding, contributing to greater swelling in the thickness of the panels. Another important factor is related to the higher densification and compacting of the panel, resulting in the release of higher compression stresses generated during the high temperature pressing process. Guimarães Junior et al. (2016) corroborate these statements, reporting that as there was inclusion of material of lower density in particleboard of Eucalyptus urophylla, increased water absorption and reduced mechanical properties were observed, facts attributed mainly to the lower availability of resin in the particles.

Regarding chemical properties, Maloney (1993) states that $\mathrm{pH}$ and extractives can directly influence the curing of the resin and, consequently, the quality of the panels produced, with values ranging from 3.0 to 5.5. According to the same author, wood with a very acidic $\mathrm{pH}$ can cause the urea-formaldehyde resin to pre-cure during the press closure phase, impairing the degree of adhesion between the particles and reducing the values of the mechanical properties of the panels. On the other hand, wood with a low acid $\mathrm{pH}$ requires a slightly higher amount of catalyst to accelerate the curing of urea-formaldehyde resin. As for the influence of extractives on the polymerization and curing of the adhesive, Moslemi (1974) states that wood with high levels of extracts presents difficulties in bonding resulting in low resistance of the adhesive bond between the particles. Rios et al. (2016) also report that a high amount of extractives interferes with the adhesive's curing time, in addition to increasing the propensity of the particleboards to occur bubbles.

In view of the above, this research was conducted with the objective of evaluating the potential use of Cupressus torulosa wood, in different proportions of mixture with Pinus taeda, for the production of particleboards.

\section{MATERIALS AND METHODS}

The wood of Cupressus torulosa D. Don was obtained from an experimental plantation at UFPR located in the city of Rio Negro - PR, with 23 years old. Five trees were collected, which were cut into $2.0 \mathrm{~m}$ logs and transported to the study site. Pinus taeda wood was purchased in the form of planks from local businesses. The resin used was urea-formaldehyde, supplied by a manufacturer in the metropolitan region of Curitiba-PR, viscosity of 430, solids content of $65.5 \%$ and $\mathrm{pH}$ of 7.8. The catalyst employed was ammonium sulfate.

The logs were processed on boards of $25 \times 200 \times 2,000 \mathrm{~mm}$ (thickness $\mathrm{x}$ width $\mathrm{x}$ length), for generating particles in a disc chipper, with the nominal dimensions of $25 \mathrm{~mm}$ in length, $0.7 \mathrm{~mm}$ in thickness and variable width. From the boards, samples were obtained to determine the basic specific masses of the wood of the species under study and the control, in addition to the compaction ratio. The average wood densities of two species in different mixing proportions were calculated based on the methodology proposed by Moslemi (1977).

After drying at an average moisture content of 3\%, the particles were reprocessed in the hammer mill to reduce the dimensions and classified in a 0.6 mesh sieve to remove "fines". Next, the particles were glued with $8 \%$ urea-formaldehyde resin, $1 \%$ paraffin emulsion and pressed at temperature of $140^{\circ} \mathrm{C}$, specific pressure of 4 $\mathrm{MPa}$ and pressing time of 8 minutes. The panels were produced with a nominal density of $0.75 \mathrm{~g} / \mathrm{cm}^{3}$ and nominal dimensions of $500 \mathrm{~mm}$ (length), $380 \mathrm{~mm}$ (width) and $13 \mathrm{~mm}$ (thickness).

Particleboards were produced with the wood of Cupressus torulosa and Pinus taeda (control), in different mixing proportions, according to the experimental design presented in table 1 . Three panels were produced per treatment, making 18 panels.

FLORESTA, Curitiba, PR, v. 50, n. 3, p. 1478 - 1485, jul/set 2020.

Iwakiri, S. et.al.

ISSN eletrônico 1982-4688

DOI: $10.5380 /$ rf.v50 i3. 61971 
Table 1. Experimental chart.

Tabela 1. Delineamento experimental.

\begin{tabular}{lc}
\hline Treatment & Panel composition - mix of species \\
\hline $\mathrm{T} 1-\mathrm{Cu} 100$ & $100 \%$ Cupressus torulosa \\
$\mathrm{T} 2-\mathrm{Cu} 80 / \mathrm{Pi} 20$ & $80 \%$ Cupressus torulosa $\mathrm{x} 20 \%$ Pinus taeda \\
$\mathrm{T} 3-\mathrm{Cu} 60 / \mathrm{Pi} 40$ & $60 \%$ Cupressus torulosa $\mathrm{x} 40 \%$ Pinus taeda \\
$\mathrm{T} 4-\mathrm{Cu} 40 / \mathrm{Pi} 60$ & $40 \%$ Cupressus torulosa $\mathrm{x} 60 \%$ Pinus taeda \\
$\mathrm{T} 5-\mathrm{Cu} 20 / \mathrm{Pi} / 80$ & $20 \%$ Cupressus torulosa $\mathrm{x} 80 \%$ Pinus taeda \\
$\mathrm{T} 6-\mathrm{Pi} 100$ & $100 \%$ Pinus taeda \\
\hline
\end{tabular}

After pressing, the panels were square and placed in a climatic chamber with a temperature of $20 \pm 2^{\circ} \mathrm{C}$ and a relative humidity of $65 \pm 3 \%$, until their stabilization at an average moisture content of $12 \%$.

To assess the physical-mechanical properties, five specimens were removed from each panel for each of the following tests: apparent specific mass, thickness swelling and water absorption after 2 and 24 hours of immersion, static bending, perpendicular traction, screw withdrawal resistance on the face and top. The tests were based on the procedures described in the standards EN 323 (1993), EN 317 (1993), EN 310 (1993), EN 319 (1993), EN 317 (1993) and NBR 14810-2 (2018), respectively.

The statistical analysis was performed based on a completely randomized design, and the results were evaluated using the Grubbs test for outliers, Shapiro Wilk test for normality, Bartlett test for homogeneity of variances and analysis of variance. As a statistically significant difference was found between specific masses, covariance analysis was applied to eliminate the effect of this variable on the other panel properties. Tukey's test at $95 \%$ significance was used to compare means, and all analyzes were performed using the Statgraphics statistical package.

\section{RESULTS}

\section{Physical properties of the panels}

The average values of basic density of wood varied from $0.440 \mathrm{~g} / \mathrm{cm}^{3}$ for Pinus taeda and $0.459 \mathrm{~g} / \mathrm{cm}^{3}$ for Cupressus torulosa (Table 2). The average values of density of the panels were all lower than the established nominal value of $0.75 \mathrm{~g} / \mathrm{cm}^{3}$ and the panels produced with $100 \%$ Cupressus torulosa wood were statistically lighter than the other types of panels. The compression ratio of all types of panels was between 1.501 and 1.666, and increased with the increase in the proportion of Pinus taeda in the panel.

Table 2. Average values of the densities and compaction ratio.

Tabela 2. Valores médios de massas específicas aparentes da madeira, painel e razão de compactação.

\begin{tabular}{lccc}
\hline Treatment & BD wood $\left(\mathbf{g} / \mathbf{c m}^{\mathbf{3}}\right)$ & D panel $\left(\mathbf{g} / \mathbf{c m}^{\mathbf{3}}\right)$ & Compaction ratio \\
\hline $\mathrm{T} 1-\mathrm{Cu} 100$ & 0.459 & $0.689(5.13) \mathrm{b}$ & $1.501(5.13) \mathrm{d}$ \\
$\mathrm{T} 2-\mathrm{Cu} 80 / \mathrm{Pi} 20$ & 0.455 & $0.713(4.83) \mathrm{a}$ & $1.566(4.82) \mathrm{c}$ \\
$\mathrm{T} 3-\mathrm{Cu} 60 / \mathrm{Pi} 40$ & 0.451 & $0.716(5.24) \mathrm{a}$ & $1.588(5.23) \mathrm{bc}$ \\
$\mathrm{T} 4-\mathrm{Cu} 40 / \mathrm{Pi} 60$ & 0.448 & $0.715(5.74) \mathrm{a}$ & $1.595(5.74) \mathrm{bc}$ \\
$\mathrm{T} 5-\mathrm{Cu} 20 / \mathrm{Pi} / 80$ & 0.444 & $0.721(6.91) \mathrm{a}$ & $1.624(6.88) \mathrm{ab}$ \\
$\mathrm{T} 6-\mathrm{Pi} 100$ & 0.440 & $0.733(5.82) \mathrm{a}$ & $1.666(5.82) \mathrm{a}$ \\
\hline
\end{tabular}

BD: basic density of wood; D: density; Averages followed by the same letter do not differ statistically at the level of probability of $95 \%$ by Tukey's test; values in parentheses correspond to the variation coefficient $(\%)$.

The average values of water absorption after 2 hours of immersion ranged from $9.87 \%$ to $12.82 \%$, with the means being statistically different between treatments (Table 3). The panels produced with mixtures of cupressus and pine in the proportions of $20 \% / 80 \%, 40 \% / 60 \%$ and $80 \% / 20 \%$ showed less water absorption, and statistically equivalent means in relation to the control panels produced with Pinus wood. 
Table 3. Average values of the physical properties of the particleboard estimated by the ANCOVA.

Tabela 3. Valores médios estimados pela ANCOVA das propriedades físicas dos painéis aglomerados.

\begin{tabular}{lcccc}
\hline Treatment & WA 2h (\%) & WA 24h (\%) & TS 2h (\%) & TS 24h (\%) \\
\hline T1 - Cu100 & $12.82 \mathrm{a}$ & $33.01 \mathrm{a}$ & $7.17 \mathrm{a}$ & $13.06 \mathrm{a}$ \\
& $(22.89)$ & $(14.66)$ & $(22.92)$ & $(16.95)$ \\
T2 - Cu80/Pi20 & $11.14 \mathrm{c}$ & $31.11 \mathrm{ab}$ & $6.02 \mathrm{a}$ & $12.19 \mathrm{ab}$ \\
& $(16.04)$ & $(11.60)$ & $(19.74)$ & $(12.99)$ \\
T3 - Cu60/Pi40 & $11.39 \mathrm{ab}$ & $32.61 \mathrm{a}$ & $5.83 \mathrm{ab}$ & $12.72 \mathrm{a}$ \\
& $(12.38)$ & $(8.03)$ & $(17.58)$ & $(13.22)$ \\
T4 - Cu40/Pi60 & $9.87 \mathrm{c}$ & $23.34 \mathrm{c}$ & $4.58 \mathrm{bc}$ & $10.73 \mathrm{bc}$ \\
& $(17.84)$ & $(13.99)$ & $(22.15)$ & $(13.49)$ \\
T5 - Cu20/Pi/80 & $10.39 \mathrm{bc}$ & $30.98 \mathrm{abc}$ & $5.96 \mathrm{a}$ & $12.24 \mathrm{ab}$ \\
& $(24.92)$ & $(21.61)$ & $(30.11)$ & $(13.12)$ \\
T6 - Pi100 & $10.78 \mathrm{bc}$ & $29.66 \mathrm{bc}$ & $4.12 \mathrm{c}$ & $9.96 \mathrm{c}$ \\
& $(26.39)$ & $(18.20)$ & $(36.59)$ & $(19.40)$ \\
\hline
\end{tabular}

WA: water absorption; TS: thickness swelling; averages followed by the same letter in the same column do not differ statistically at the 95\% probability level by the Tukey test; Values adjusted by covariance analysis for an apparent specific mass of $0.72 \mathrm{~g} / \mathrm{cm}^{3}$; values in parentheses correspond to the variation coefficient (\%).

For water absorption after 24 hours of immersion, the average values ranged from $23.34 \%$ to $33.01 \%$, the means being statistically different between treatments for panels with $100 \%$ Cupressus (T1), with the averages being statistically different from each other. The panels produced with mixtures of cupressus and pine in the proportions of $20 \% / 80 \%$ and $40 \% / 60 \%$ showed less water absorption, and averages statistically equivalent in relation to the panels produced with $100 \%$ Pinus wood.

The average values of thickness swelling after 2 hours of immersion ranged from $4.12 \%$ to $7.17 \%$, with the means being statistically different between treatments. For thickness swelling after 24 hours of immersion, the mean values ranged from $9.96 \%$ to $13.06 \%$, with the means being statistically different between treatments. Both for 2 hours and for 24 hours of immersion, the panels produced with mixtures of cupressus and pine in the proportions of $40 \% / 60 \%$ showed less swelling in thickness, and statistically equivalent means in relation to the control panels, produced with Pinus wood.

\section{Mechanical properties of panels}

The mean values of modulus of rupture ranged from $14.41 \mathrm{MPa}$ to $17.16 \mathrm{MPa}$, with the means being statistically different between treatments (Table 4). All panels produced with $100 \%$ Cupressus and different proportions of mixtures with Pinus showed statistically equivalent means in relation to the control panels, produced with Pinus wood.

Table 4. Average values of the mechanical properties of the particleboard estimated by the ANCOVA.

Tabela 4. Valores médios estimados pela ANCOVA das propriedades mecânicas dos painéis aglomerados.

\begin{tabular}{|c|c|c|c|c|c|}
\hline Treatment & MOR (MPa) & MOE (MPa) & $\begin{array}{c}\text { TP } \\
\text { (MPa) }\end{array}$ & $\begin{array}{c}\text { SWR face } \\
(\mathrm{N})\end{array}$ & $\begin{array}{c}\text { SWR topo } \\
(\mathrm{N})\end{array}$ \\
\hline $\mathrm{T} 1-\mathrm{Cu} 100$ & $\begin{array}{c}16.07 \mathrm{ab} \\
(13.64)\end{array}$ & $\begin{array}{c}2.521 \mathrm{ab} \\
(17.27)\end{array}$ & $\begin{array}{c}0.76 \mathrm{a} \\
(16.49)\end{array}$ & $\begin{array}{c}1.177 \mathrm{a} \\
(9.94)\end{array}$ & $\begin{array}{c}1.279 \mathrm{a} \\
(6.53)\end{array}$ \\
\hline $\mathrm{T} 2-\mathrm{Cu} 80 / \mathrm{Pi} 20$ & $\begin{array}{c}17.16 \mathrm{a} \\
(7.54)\end{array}$ & $\begin{array}{c}2.583 \mathrm{a} \\
(7.68)\end{array}$ & $\begin{array}{c}0.70 \mathrm{a} \\
(21.33)\end{array}$ & $\begin{array}{l}1.123 \mathrm{a} \\
(15.81)\end{array}$ & $\begin{array}{c}1.128 \mathrm{ab} \\
(13.18)\end{array}$ \\
\hline T3 - Cu60/Pi40 & $\begin{array}{c}15.88 \mathrm{ab} \\
(16.36)\end{array}$ & $\begin{array}{c}2.500 \mathrm{ab} \\
(11.55)\end{array}$ & $\begin{array}{c}0.71 \mathrm{a} \\
(16.77)\end{array}$ & $\begin{array}{l}1.227 \mathrm{a} \\
(14.59)\end{array}$ & $\begin{array}{c}853 \mathrm{~b} \\
(12.37)\end{array}$ \\
\hline $\mathrm{T} 4-\mathrm{Cu} 40 / \mathrm{Pi} 60$ & $\begin{array}{c}14.60 \mathrm{~b} \\
(9.15)\end{array}$ & $\begin{array}{c}2.142 \mathrm{~cd} \\
(8.38)\end{array}$ & $\begin{array}{c}0.77 \mathrm{a} \\
(19.79)\end{array}$ & $\begin{array}{c}1.109 \mathrm{a} \\
(9.88)\end{array}$ & $\begin{array}{l}1.062 \mathrm{~b} \\
(10.85)\end{array}$ \\
\hline $\mathrm{T} 5-\mathrm{Cu} 20 / \mathrm{Pi} / 80$ & $\begin{array}{c}14.41 \mathrm{~b} \\
(9.60)\end{array}$ & $\begin{array}{l}2.134 d \\
(10.66)\end{array}$ & $\begin{array}{c}0.77 \mathrm{a} \\
(22.20)\end{array}$ & $\begin{array}{l}1.168 \mathrm{a} \\
(17.87)\end{array}$ & $\begin{array}{c}1.155 \mathrm{ab} \\
(23.00)\end{array}$ \\
\hline T6 - Pi100 & $\begin{array}{c}15.57 \mathrm{ab} \\
(14.58)\end{array}$ & $\begin{array}{c}2.344 \mathrm{bc} \\
(12.88)\end{array}$ & $\begin{array}{c}0.81 \mathrm{a} \\
(21.33)\end{array}$ & $\begin{array}{l}1.121 \mathrm{a} \\
(27.17)\end{array}$ & $\begin{array}{c}1.135 \mathrm{ab} \\
(20.99)\end{array}$ \\
\hline
\end{tabular}

MOR: modulus of rupture; MOE: modulus of elasticity; TP: traction perpendicular to the surface; SWR: screw withdrawal resistance; averages followed by the same letter in the same column do not differ statistically at the 95\% probability level by the Tukey test; Values adjusted by covariance analysis for an apparent specific mass of $0.72 \mathrm{~g} / \mathrm{cm} 3$; values in parentheses correspond to the variation coefficient $(\%)$.

FLORESTA, Curitiba, PR, v. 50, n. 3, p. 1478 - 1485, jul/set 2020.

Iwakiri, S. et.al.

ISSN eletrônico 1982-4688

DOI: $10.5380 /$ rf.v50 i3. 61971 
The mean values of modulus of elasticity ranged from 2,134 MPa to 2,583 MPa, the means being statistically different between treatments. The panels produced with $100 \%$ Cupressus showed a statistically equivalent average in relation to the panels produced with mixtures with Pinus of $80 \% / 20 \%$ and $60 \% / 40 \%$, and higher in comparison to the control panels, produced with Pinus wood.

The average values of perpendicular traction ranged from $0.70 \mathrm{MPa}$ to $0.81 \mathrm{MPa}$, the averages being statistically equivalent among all treatments.

The average values of screw withdrawal resistance on the surface ranged from $1,109 \mathrm{~N}$ to $1,227 \mathrm{~N}$. There were no statistically significant differences between all treatments evaluated.

For the screw withdrawal at the top, the average values ranged from $853 \mathrm{~N}$ to $1,279 \mathrm{~N}$, the averages being statistically different between treatments. The panels produced with $100 \%$ Cupressus showed a statistically equivalent average in relation to the control panels, produced with $100 \%$ Pinus, with mixtures of $80 \% / 20 \%$ and $20 \% / 80 \%$, and higher compared to the other treatments.

\section{DISCUSSION}

The results of the basic density of the wood of Cupressus and Pinus, in addition to the mixture of these in different proportions, meet the recommendations by Moslemi (1974) for the production of particleboard up to $0.55 \mathrm{~g} / \mathrm{cm}^{3}$.

The density values of the panels were slightly lower than the nominal specific mass calculated at 0.750 $\mathrm{g} / \mathrm{cm}^{3}$. The differences observed between treatments can be attributed to the loss of material during the formation of the panels and an increase in volume due to the return in thickness after hot pressing followed by conditioning. The low coefficients of variation indicate that there were no significant variations in the formation of the panels.

The results of the compaction ratio of panels produced with Cupressus wood, pure or in different proportions of mixture with Pinus, were higher than the minimum value of 1.3 (MOSLEMI, 1974), recommended for the production of particleboards.

Significant differences were found for water absorption and thickness swelling of the panels of different treatments. However, the variations in the basic density of the wood of the two species and their mixture were small, and it is not possible to conclude about the influence of the lower density of the wood and the higher compaction ratio of the panels in reducing water absorption, contrary to the concepts reported by Moslemi (1974). All treatments showed average values of swelling in thickness 24 hours below 15\%, as established by standard EN 312 (1993), for structural panels with use in dry conditions (P4) and below 14\% for non-structural panels with application in wet conditions (P3), with thickness between 13 and $20 \mathrm{~mm}$. For panels used in dry environments, including furniture, this standard has no minimum requirement.

The results of water absorption 24 hours were satisfactory when compared to some references presented in the literature on experimental particleboards produced with species from forest plantations. Rosa et al. (2017) found for particleboards produced with five species of Eucalyptus (E. benthamii, E. dunnii, E. grandis, E. saligna, E. urograndis) 24-hour water absorption values in the range of $22.28 \%$ to $29.82 \%$. Trianoski et al. (2011) found for panels of Acrocarpus fraxinifolius, Melia azedarach, Grevillea robusta, Schizolobium parahyba (Vell), Blake and Toona ciliata, values in the range of $32.06 \%$ to $68.70 \%$. Trianoski et al. (2013) and Iwakiri et al. (2014) obtained for 24-hour water absorption values of $17.39 \%$ and $55.40 \%$ for Cryptomeria japonica and Sequoia sempervirens, respectively.

Regarding the 24-hour thick swelling, the results are compatible with some values presented in the literature. Rosa et al. (2017) found for particleboards produced with five species of Eucalyptus (E. benthamii, E. dunnii, E. grandis, E. saligna, E. urograndis) 24-hour thick swelling values in the range of $10.74 \%$ to $11.76 \%$. Trianoski et al. (2011) found for Acrocarpus fraxinifolius, Melia azedarach, Grevillea robusta, Schizolobium parahyba and Toona ciliata, values in the range of $16.78 \%$ to $29.76 \%$.

All the panels produced with $100 \%$ Cupressus wood, or in different proportions of mixture with Pinus, presented average values of MOR, statistically equal in comparison to the control panels, produced with $100 \%$ of Pinus. Likewise, all treatments met the requirement of standard EN 312 (1993), which specifies a minimum value of $13 \mathrm{MPa}$ and $14 \mathrm{MPa}$ for MOR, respectively for classes P2 and P3 (13 to $20 \mathrm{~mm}$ ). The influence of the compaction ratio of the panels on the MOR was not found.

The average values of MOR were satisfactory when compared to the results presented by some researchers for particleboards produced with species from forest plantations. Rosa et al. (2017) found particleboards produced with five species of Eucalyptus (E. benthamii Maiden et Cambage, E. dunnii Maiden, E. grandis Hill, E. saligna (Sm.), E. urograndis) values of MOR ranging from $15.82 \mathrm{MPa}$ to 20.82 MPa. Trianoski

FLORESTA, Curitiba, PR, v. 50, n. 3, p. 1478 - 1485, jul/set 2020.

Iwakiri, S. et.al.

ISSN eletrônico 1982-4688

1482

DOI: 10.5380/rf.v50 i3. 61971 
et al. (2011) found for panels of Acrocarpus fraxinifolius, Melia azedarach, Grevillea robusta, Schizolobium parahyba and Toona ciliata, values ranging from 7.04 MPa to $19.83 \mathrm{MPa}$.

As for the MOE, with the exception of panels produced with a mixture of $20 \%$ Cupressus and $80 \%$ Pinus, all other treatments showed an average greater than or equal to the control panel with $100 \%$ Pinus wood. All treatments met the requirement of standard EN 312 (1993) which specifies for MOE, a minimum value of 1,600 MPa and $1950 \mathrm{MPa}$, for classes P2 and P3 (13 to $20 \mathrm{~mm}$ ). The influence of the compaction ratio on the panel's MOE was not found.

The average values of MOE were satisfactory compared to the results presented by some researchers for particleboards produced with species from forest plantations. Rosa et al. (2017) found for particleboards produced with five species of Eucalyptus (E. benthamii, E. dunnii, E. grandis, E. saligna, E. urograndis) MOR values ranging from 2,111 $\mathrm{MPa}$ to $2,589 \mathrm{MPa}$. Trianoski et al. (2011) found for panels of Acrocarpus fraxinifolius, Melia azedarach, Grevillea robusta, Schizolobium parahyba and Toona ciliata, values ranging from 1,475 MPa to 2,427 MPa.

All panels produced with 100\% Cupressus and different proportions of mixture with Pinus showed statistically equivalent mean values of perpendicular tension in comparison to the control panels, produced with 100\% Pinus wood. All treatments met the requirement of standard EN 312 (1993), which specifies a minimum value of 0.35 and $0.45 \mathrm{MPa}$ for perpendicular traction, for use classes P2 and P3 (13 to $20 \mathrm{~mm}$ ), respectively. The influence of the compaction ratio of the panels on the perpendicular traction was not verified.

The results of perpendicular traction are in accordance with the results presented by Rosa et al. (2017) or particleboards produced with five species of Eucalyptus (E. benthamii, E. dunnii, E. grandis, E. saligna, E. urograndis), ranging from 0.64 MPa 0.91 MPa. Trianoski et al. (2013) and Iwakiri et al. (2014), found for panels of Cryptomeria japonica and Sequoia sempervirens, perpendicular tensile values of 0.99 MPa and 0.70, respectively. Colli, et al. (2010) found an average value of $0.22 \mathrm{MPa}$ for Schizolobium amazonicum.

With respect to the screw withdrawal resistance, both for the surface and for the top, all panels produced with 100\% Cupressus and different proportions of mixture with Pinus, showed statistically equal results in comparison to the control panels, produced with $100 \%$ of Pinus wood. All treatments met the minimum requirements of standard NBR 14810-2 (2018) class M1N.S, of 1,020 N for the surface and $800 \mathrm{~N}$ for the top of the panels. The compaction ratio of the panels did not influence the results of screw withdrawal resistance.

The results of screw withdrawal to the surface and top of the panels are in accordance with some values presented in the literature. Trianoski et al. (2016) found average values of $990 \mathrm{~N}$ for the surface and $824 \mathrm{~N}$ for the top for Grevillea robusta panels. Cunha et al. (2014) ound, for panels produced with Eucalyptus benthamii, Eucalyptus dunnii and Eucalyptus grandis, average values of screw withdrawal resistance on the surface and top, in the range of $1,042 \mathrm{~N}$ to $1,472 \mathrm{~N}$.

\section{CONCLUSIONS}

Based on the results obtained, the following conclusions can be presented:

- The compaction ratio of the panels produced with $100 \%$ of the species, and, in different proportions of mixtures, did not significantly influence the results of the properties of the particleboards.

- For all evaluated treatments, the average values of swelling in thickness 24 hours, modulus of rupture, modulus of elasticity and perpendicular traction met the minimum requirements established by standard EN 312 (2010) for panels in use in dry environments including furniture (P2) and non-structural panels for use in wet conditions (P3), and screw withdrawal resistance in relation to the requirements of NBR 14810-2 (2018) M1N.S.

- The comparative evaluations of the results of this research, with Pinus taeda, which is the species most used commercially in Brazil, in addition to the normative requirements of EN 312 (2003) for commercial panels, demonstrated that the species Cupressus torulosa has great potential for the production of particleboards.

\section{REFERÊNCIAS}

ALMEIDA, C. C. F.; CUNHA, A. B.; RIOS, P. Avaliação da qualidade da colagem de topo da madeira de Cupressus lusitânica para a produção de painéis colados lateralmente. Scientia Forestalis, Piracicaba, v. 43, n. 13, p. 1-19, 2017.

ASSOCIAÇÃO BRASILEIRA DE NORMAS TÉCNICAS - ABNT. NBR 14810 - 2. Painéis de partículas de média densidade. Parte 2: Requisitos e métodos de ensaio. Rio de Janeiro, 71p., 2018.

FLORESTA, Curitiba, PR, v. 50, n. 3, p. 1478 - 1485, jul/set 2020.

Iwakiri, S. et.al.

ISSN eletrônico 1982-4688

1483

DOI: $10.5380 /$ rf.v50 i3. 61971 
BIANCHE, J. J.; CARNEIRO, A. C. O.; VITAL, B. R.; PEREIRA, F. A.; SANTOS, R. C.; SORATTO, D. N. Propriedades de painéis aglomerados fabricados com partículas de eucalipto (Eucalyptus urophylla), paricá (Schizolobium amazonicum) e vassoura (Sida spp.). Cerne, Lavras, v. 18, n. 4, p. 623-630, 2012.

COLli, A.; VITAL, B. R.; CARNEIRO, A. C. O.; SILVA, J. C.; CARVALHO, A. N. M. L.; DELLA LUCIA, R. M. Properties of panels manufactured with wood particles of paricá (Schizolobium Huber ex. Ducke) and coconut fibers. Revista Árvore, Viçosa, v. 34, p. 333 - 338, 2010.

CUNHA, A. B.; LONGO, B. L.; RODRIGUES, A. A.; BREHMER, D. R. Produção de painéis de madeira aglomerada de Eucalyptus benthamii, Eucalyptus dunnii e Eucalyptus grandis. Scientia Forestalis, Piracicaba, v. 42, n. 102, p. $259-267,2014$.

EUROPEAN COMMITTEE FOR STANDARDIZATION - CEN. EN 310. Wood-based panels - Determination of modulus of elasticity in bending and of bending strength. Brussels, 1993.

EUROPEAN COMMITTEE FOR STANDARDIZATION- CEN. EN 312. Particleboards - Specifications. Brussels, 2010.

EUROPEAN COMMITTEE FOR STANDARDIZATION - CEN. EN 317. Particleboards and fibreboards Determination of swelling in thickness after immersion in water. Brussels, 1993.

EUROPEAN COMMITTEE FOR STANDARDIZATION - CEN. EN 319. Particleboards and fibreboards Determination of tensile strength perpendicular to the plane of the board. Brussels, 1993.

EUROPEAN COMMITTEE FOR STANDARDIZATION - CEN. EN 323. Wood-based panels - Determination of board density. Brussels, 1993.

GUIMARÃES, J. B.; XAVIER, M. M.; SANTOS, T. S.; PROTÁSIO, T. S.; MENDES, R. F.; MENDES, L.M. Inclusão de resíduo da cultura de sorgo em painéis aglomerados de eucalipto. Pesquisa Florestal Brasileira, Colombo, v. 36, n. 88, p. 435-442, 2016.

IWAKIRI, S.; TRIANOSKI, R.; CUNHA, A. B.; CASTRO, V. G.; BRAZ, R. L.; VILLAS BOAS, B. T.; SANCHES, F. L.; BELLON, K. R. R. Evaluation of the quality of particleboard manufactured with wood from Sequoia sempervirens and Pinus taeda. Cerne, Lavras, v. 20, p. 209 - 216. 2014.

MALONEY, T. M. Modern particleboard \& dry-process fiberboard manufacturing. San Francisco: Miller Freeman Inc., 1993. 689 p.

MARTINS, E. H.; GUIMARÃES, J. B.; PROTÁSIO, T. P.; MENDES, R. F.; MENDES, L. M. Painéis aglomerados convencionais produzidos com madeira de Cecropia pachystachya. Enciclopédia Biosfera, v. 10, n.19; p. 2014.

MOSLEMI, A. A. Particleboard. London: Southern Illinois University Press, 1974. 245 p.

NAUMANN, R. B.; VITAL, B. R.; CARNEIRO, A. C. O.; DELlA LUCIA, R. M.; SILVA, J. C.; CARVALHO, A. M. M. L.; COLLI, A. Properties of particleboard manufactured from Eucalyptus urophylla S. T. Blake and Schizolobium amazonicum Huber ex. Ducke. Revista Árvore, Viçosa, v. 32, p. 1143 - 1150, 2008.

OKINO, E. Y. A.; SOUZA, M. R.; SANTANA, M. A. E.; ALVES, M. V. S.; SOUSA, M. E.; TEIXEIRA, D. E. Physico-mechanical properties and decay resistance of Cupressus spp. Cement-bonded particleboards. Cement \& Concrete Composites, Hong Kong, v. 27, p. 333 - 338, 2005.

OKINO, E. Y. A.; TEIXEIRA, D. E.; SOUZA, M. R.; SANTANA, M. A. E.; SOUSA M. E. Propriedades de chapas OSB de Eucalyptus grandis e de Cupressus glauca. Scientia Forestalis, Piracicaba, v. 36, n. 78, p. 123$131,2008$.

OKINO, E. Y. A.; SANTANA, M. A. E.; AlVES, V. S. A.; MELO, J. E.; CORADIN, V. T.; SOUZA, M. R.; TEIXEIRA, D.; SOUSA, M. E. Technological characterization of Cupressus spp. wood. Floresta e Ambiente, Seropédica, v. 17, n. 1, p. 1-11, 2010.

RIOS, P. A.; PEREIRA, G. F.; VIEIRA, H.; GRUBERT, W.; CUNHA, A. C.; BRAND, M. A. Avaliação do potencial da madeira de Pinus patula Schltdl. \& Cham para a produção de painéis de madeira aglomerada. Scientia Forestalis, Piracicaba, v. 44, n. 110, p. 497-508, 2016.

FLORESTA, Curitiba, PR, v. 50, n. 3, p. 1478 - 1485, jul/set 2020. 
ROSA, T. S.; TRIANOSKI, R.; IWAKIRI, S.; BONDUELLE, G. M. Use of five Eucalyptus species for particleboard manufacture. Revista Árvore, Viçosa, v. 41, n. 2, p. 1 - 8, 2017.

TRIANOSKI, R.; IWAKIRI, S.; MATOS, J. L. M. Potential use of planted fast-growing species for production of particleboard. Journal of Tropical Forest Science, Kepong, v. 23, p. 311 - 317, 2011.

TRIANOSKI, R.; IWAKIRI, S; MATOS, J. L. M.; CHIES, D. Utilização da madeira de Cryptomeria japonica para produção de painéis aglomerados. Scientia Forestalis, Piracicaba, v. 41, n. 97, p. 57 - 64, 2013.

TRIANOSKI, R.; PICCARDI, A. B. R.; IWAKIRI, S.; MATOS, J. L. M.; BONDUELLE, G. M. Incorporação de Grevillea robusta na produção de painéis aglomerados de Pinus spp. Floresta \& Ambiente, Seropédica, v. 23, p. $278-285,2016$.

ZELLER, F.; BARBU, M. C.; IWAKIRI, S. Paricá (Schizolobium amazonicum) and embaúba (Cecropia sp.) as new materials for particleboards. European Journal of Wood Products, Berlin, v. 71, p. 823 - 825, 2013. 